\section{Severe acute respiratory syndrome coronavirus 2 in cats: a systematic review}

\author{
Síndrome respiratória aguda por coronavírus em gatos: uma \\ revisão sistemática
}

\author{
Ana Izabel Passarella Teixeira' (1) \& Ligia Cantarino2* (D) \\ 'Veterinarian, DSc., Núcleo de Medicina Tropical, Universidade de Brasília (UNB), Brasília, DF, Brazil. \\ ²Veterinarian, DSc., Faculdade de Agronomia e Veterinária, UNB, Brasília, DF, Brazil.
}

\begin{abstract}
The epidemiological role of cats in the coronavirus disease pandemic remains unclear despite of several studies that have been conducted to understand it, in other words it is not yet known whether the cat would be able to transmit severe acute respiratory syndrome coronavirus 2 (SARS-CoV-2) to humans. Taking that into account, the objective of this study was to conduct a systematic review to identify what is known and not known on this topic. Our results revealed that cats can be infected through an airborne (perhaps oral, too) route and that the clinical development of the infection in cats is parallel to that in humans. The majority of infected cats remained asymptomatic, and more severe clinical cases described occurred only in animals with comorbidities. In addition to infection, cats achieved seroconversion with detectable titers. However, the epidemiological role of cats in relation to transmission routes of severe acute respiratory syndrome coronavirus 2 (SARS-CoV-2) remains unclear and needs to be studied further. We emphasize that, regardless of the conclusion regarding the epidemiological role of cats, this reinforces the concepts of ONE HEALTH to be incorporated into the studies and practices of epidemiological surveillance of infectious diseases, with multidisciplinary teams, to achieve an understanding of the transmission of diseases with zoonotic potential.
\end{abstract}

Keywords: domestic cat, epidemiology, SARS-CoV-2.

\section{Resumo}

O papel epidemiológico dos gatos na pandemia da doença causada pelo novo coronavírus ainda não foi esclarecido. Apesar de vários estudos realizados, ainda não foi determinado se os gatos poderiam transmitir o vírus da síndrome respiratória aguda grave coronavírus 2 (SARS-CoV-2) para os humanos. Diante disso, o objetivo deste estudo foi realizar uma revisão sistemática sobre esse tema. Nossos resultados destacam os achados de que os gatos podem ser infectados por via aérea, talvez oral também, e de que o desenvolvimento clínico da infecção em gatos guarda um paralelo com a infecção em humanos, pois a maioria dos gatos infectados que foram estudados permaneceu assintomática, e os casos clínicos mais graves descritos ocorreram apenas em animais com comorbidades. Além da presença do vírus, os gatos também desenvolvem anticorpos específicos. Ressaltamos que, independentemente da conclusão quanto ao papel epidemiológico dos gatos, os achados desse estudo reforçam os conceitos de ÚNICA SAÚDE a serem incorporados aos estudos e práticas de vigilância epidemiológica de doenças infecciosas, com equipes multidisciplinares, para o entendimento da transmissão de doenças com potencial zoonótico.

Palavras-chave: gatos domésticos, epidemiologia, SARS-CoV-2.

\section{Introduction}

Severe acute respiratory syndrome coronavirus 2 (SARS-CoV-2), the causative agent of an unprecedented pandemic of coronavirus disease (COVID-19) (47 million confirmed cases and more than 1 million deaths [World Health Organization, 2020]), has been intensively studied to better understand how this virus has developed and spread around the world. Among these epidemiological studies, its zoonotic potential and ability to infect several species of animals have been explored (Morais et al., 2020).

In these studies, cats have received more attention because of the scientific evidence that these animals can be infected by humans and can transmit it to other cats, as well as presentation of a humoral response with neutralizing antibodies (Halfmann et al., 2020; Morais et al., 2020; Zhang et al., 2020). Other studies have also revealed that cats are more susceptible to SARS-CoV-2 than dogs, due
How to cite: Teixeira, A. I. P., \& Cantarino, L. (2021) Severe acute respiratory syndrome coronavirus 2 in cats: a systematic review. Brazilian Journal of Veterinary Medicine, 43, e000421. https://doi. org/10.29374/2527-2179.bjvm000421

Received: February 21, 2021.

Accepted: May 11, 2021.

\section{*Correspondence}

Ligia Cantarino

Faculdade de Agronomia e Medicina Veterinária, Universidade de Brasília - UnB

Campus Universitário Darcy Ribeiro, s/n CEP 70910-900 - Brasília (DF), Brasil

E-mail: ligiacantarino@unb.br 
to a greater expression of angiotensin converting enzyme 2 (ACE2), as there is a greater homology of feline ACE2 than of canine ACE2 with human ACE2 (Alexander et al., 2020; Mathavarajah \& Dellaire, 2020; Dhama et al. 2020).

The epidemiological role of cats in relation to COVID-19 needs to be accurately assessed in view of the importance of these discoveries in combating the pandemic. Therefore, this study aimed to present a systematic review of the epidemiological, clinical, and diagnostic aspects already identified in cats with SARS-CoV-2 to precisely contribute to this assessment.

\section{Materials and methods}

Searches for scientific articles were carried out on PubMed, Scopus, and SciELO databases with the keywords "SARS-CoV-2," "cat," and "feline" and in combinations such as "SARS-CoV-2" and "cat" or "feline," "SARS-CoV-2, and cat," and "SARS-CoV-2 and feline." The search included original articles, review articles, letters to the editor, and comments to capture all possible relevant information to describe the possible epidemiological role of the domestic cat in the transmission of SARS-CoV-2.

The articles were selected in four stages: first, the titles were read; second, their summaries were read; third, the entire content of each article was read; and finally, duplicates were removed. Subsequently, the selected articles as well as any relevant literature cited in those articles were recorded (Figure 1).

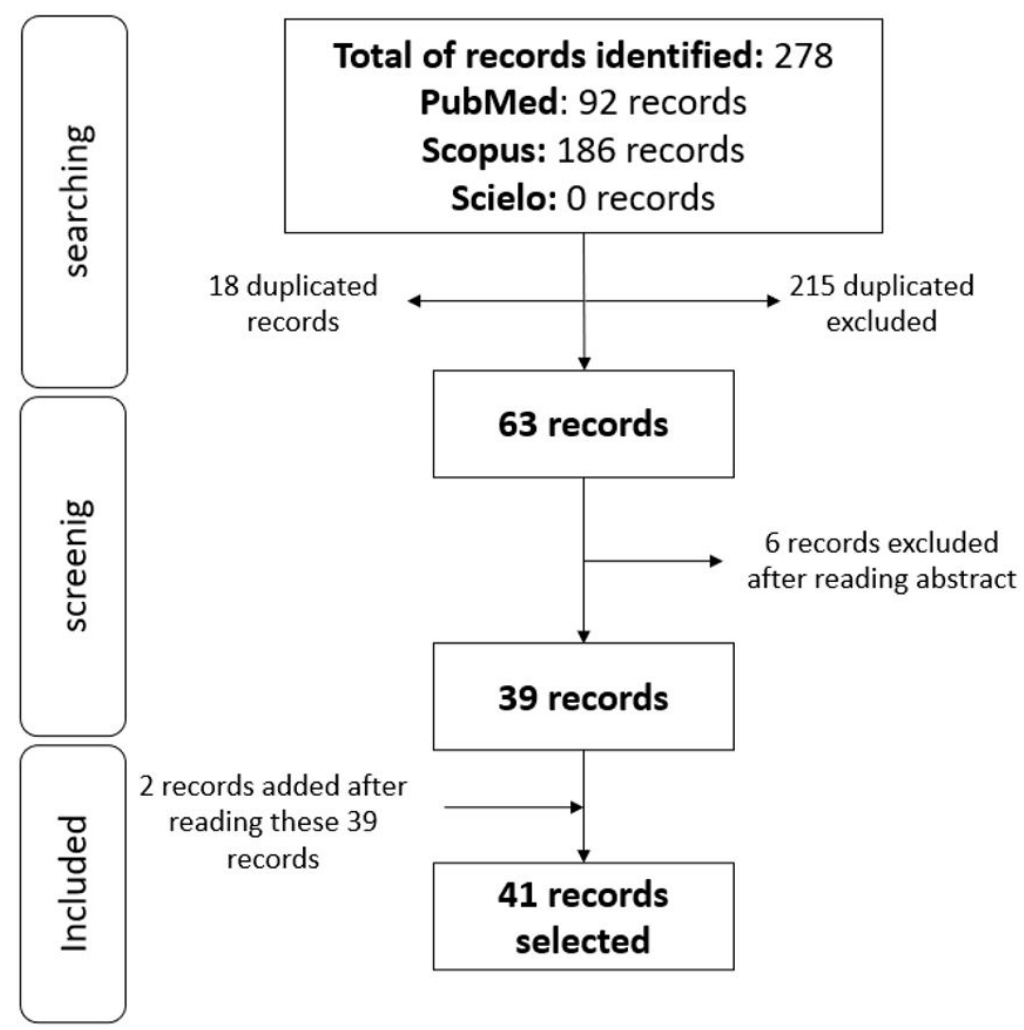

Figure 1. Retrieval flow chart.

The scientific evidence presented by the articles was also cataloged in the form shown below in the Results section.

\section{Results}

On October 28, 2020, the keywords and appropriate combinations were searched. Initially, 92 articles were retrieved from PubMed and 186 from Scopus. No articles were found in the SciELO. After the titles were read, 215 articles were discarded, either because they were about 
CAT scans (the vast majority) or because they did not fit the established criteria to be included in the study. Of the remaining 63 articles, six possibilities of treating COVID-19 with drugs for the treatment of feline infectious peritonitis were excluded, and it was found that 18 were repeated. Two other articles were included from the articles that were already selected.

The findings were grouped into epidemiological, clinical, and immunological aspects so that the possible epidemiological role of cats in this SARS-COV-2 pandemic could be analyzed in a broader way. The main findings are summarized in Table 1.

Table 1. Main scientific findings of cats with SARS-COV-2.

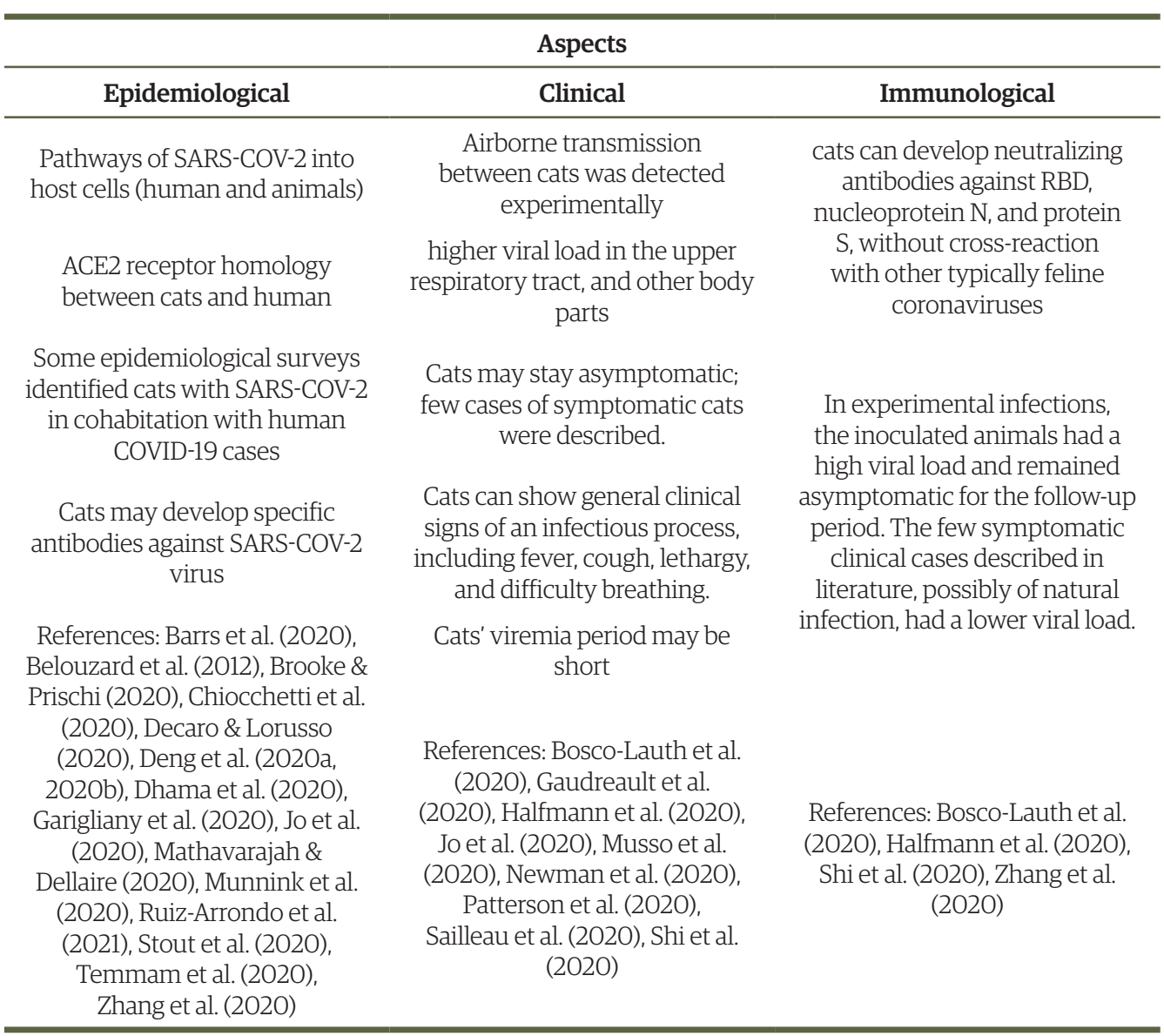

\section{Discussion}

\section{Epidemiological aspects}

Domestic animals, especially pets, are being evaluated to better understand their possible epidemiological role in the transmission of SARS-CoV-2. Given the novelty of this virus, many bioinformatics tests, experiments to evaluate the route of entry of SARS-CoV-2 into the cells, and simulations have been performed.

The SARS-CoV-2 entry pathway in host cells occurs through the interaction of glycoprotein $S$ with the cell's ACE2 receptor, which is expressed in the cells of several mammalian species (Belouzard et al., 2012; Brooke \& Prischi, 2020). In felines, it is expressed in several cell types, including the skin cells (Chiocchetti et al., 2020; Sun et al., 2020). Through a combination of this information with the results of an experimental infection of feline cell cultures, descriptions of clinical cases (with positive reverse transcription polymerase chain reaction [RT-qPCR] results), and SARS-CoV-2 transmission between cats, they have been established as SARS-CoV-2 hosts (Chiocchetti et al., 2020; Halfmann et al., 2020; Luan et al., , 2020). 
Surveillances of human patients with COVID-19 who lived with cats revealed that SARS-CoV-2 was detected in 6 of 50 cats (12\%), and samples from a cat owner with COVID-19 and his cat were sequenced and considered identical (Barrs et al., 2020). In a seroepidemiological survey in Italy, the seroprevalence of antibodies against SARS-CoV-2 in cats was 3.9\%; however, no RT-PCR results were positive (Decaro \& Lorusso, 2020), which raises questions about the time of viremia in these animals.

Zhang et al. (2020) performed serological tests on cats in Wuhan, the city where the COVID-19 pandemic began, and found that 14.7\% (15/102) of feline sera collected during the outbreak showed antibodies against the receptor-binding domain (RBD), with high titers of neutralizing antibodies (ranging from $1 / 20$ to 1/1,080). In addition, western blotting verified the presence of specific IgGs against protein S and protein N of SARS-CoV-2 in cats. Furthermore, the sequencing of virus samples identified in felines performed by Ul-Rahman et al. (2020) was phylogenetically identical to that of the Wuhan strains.

Temmam etal. (2020) examined dogs and cats that lived with veterinary medicine students who contracted COVID-19. As RT-PCR from swabs and serological tests did not detect the presence of the virus or any immunological response, they concluded that the transmission capacity of humans to animals might be low. However, this study evaluated only a small group (9 cats and 12 dogs that lived with 18 students). Additionally, in the period from the index case until the animals were tested, few animals showed characteristic symptoms of respiratory infection that were spontaneously cured.

In a seroepidemiological survey conducted in China, Deng et al. (2020a) did not detect antibodies in any of the cats analyzed. In view of the disagreement between their results and those of other studies, Deng et al. (2020b) published a comment in which they raised the hypothesis that cats become infected when they have close contact with humans.

There are still controversies about the potential epidemiological role of felines in the transmission of SARS-CoV-2. Cats can acquire SARS-CoV-2 from humans (Barrs et al., 2020; Garigliany et al., 2020; Ruiz-Arrondo et al., 2021), but there is still no evidence that humans can acquire SARS-CoV-2 from cats or how often this occurs. It is worth noting that, since the beginning of the pandemic, the only case of animal-human transmission has recently been reported in Denmark, where transmission of SARS-CoV-2 occurred from a mink to a human. This fact, together with some detected mutations (Munnink et al., 2020), could make this virus even more infectious, culminating in the decision to slaughter the entire mink herd in Denmark (European Centre for Disease Prevention and Control, 2020).

Nevertheless, it seems reasonable to think that even though the infection of humans by felines is a rare event, in terms of populations of countries, or even the world, this possibility may be relevant because of the absolute number of cases that this event can represent (Morais et al., 2020).

\section{Clinical aspects and viral identification}

To investigate how cats can contract SARS-CoV-2, become ill, and transmit SARS-CoV-2 to other animals or humans, studies have been conducted using experimental infection in cats. Shi et al. (2020) infected seven young cats intranasally with strains of SARS-CoV-2 and placed the infected cats in cages next to other cages with uninfected cats to check for airborne transmission. Owing to the aggressive behavior of these cats, intranasal lavages were not performed, but stool samples were analyzed to assess the presence of the virus. On day 3 post-infection, virus particles were detected in the feces of one of the uninoculated animals. These animals were euthanized, and the virus was detected in the upper airways (soft palate, tonsils, nasal sinuses, trachea, lungs, and intestines). Transmission between cats was also experimentally detected by Halfmann et al. (2020), where the presence of the virus was detected in rectal swabs and fresh feces, raising questions about the possibility of a fecal-oral transmission route (Gaudreault et al., 2020; Shi et al., 2020).

In other studies of experimental infections in cats, no apparent clinical signs were observed, and the animals remained asymptomatic during all theexperiments (Gaudreault etal.2020). These authorsalso detected the presence of the virus throughout the respiratory and digestive tracts, where the viral load was higher in the upper respiratory tract than in the bronchi. These findings corroborate the results of Shi etal.(2020) and Halfmann et al. (2020) who showed that the virus could be transmitted from cats to cats through air. Therefore, considering that there is a possibility of transmission of asymptomatic cats, this may be one of the explanations of why SARS-CoV-2 has spread so quickly around the world. 
Bosco-Lauth et al. (2020) recommend the use of cats as models to investigate the transmission of SARS-CoV-2, as they also found a higher viral load in the upper respiratory tract, including the development of some injuries in these tissues due to viral infection. Furthermore, according to clinical case reports, cats can show general clinical signs of an infectious process, including fever, cough, lethargy, and difficulty breathing (Table 2).

Table 2. Clinical reports of COVID-19 in cats.

\begin{tabular}{|c|c|c|c|c|}
\hline Country & $\begin{array}{l}\text { In contact with a } \\
\text { human patient with } \\
\text { COVID-19? Human-cat } \\
\text { transmission? }\end{array}$ & $\begin{array}{l}\text { Did the cat exhibit } \\
\text { clinical symptoms? }\end{array}$ & Diagnostic tests & References \\
\hline Belgium & Yes, its owner & $\begin{array}{c}\text { Asymptomatic } \\
\text { period and period } \\
\text { with general clinical } \\
\text { signs of infectious } \\
\text { processes (cough, } \\
\text { difficulty breathing, } \\
\text { prostration) evolved } \\
\text { with spontaneous } \\
\text { cure }\end{array}$ & $\begin{array}{l}\text { RT-PCR detection of } \\
\text { viral RNA in samples } \\
\text { of oropharyngeal } \\
\text { swabs, feces } \\
\text { and vomiting. } \\
\text { Neutralizing } \\
\text { antibodies detected } \\
\text { by different } \\
\text { serological tests }\end{array}$ & $\begin{array}{l}\text { Garigliany et al. } \\
\text { (2020) }\end{array}$ \\
\hline $\begin{array}{l}\text { United } \\
\text { States }\end{array}$ & $\begin{array}{l}\text { Suspicious because } \\
\text { owners had COVID-19' } \\
\text { symptoms first }\end{array}$ & $\begin{array}{c}\text { Two animals } \\
\text { identified with } \\
\text { general clinical signs } \\
\text { (lethargy, cough, and } \\
\text { eye discharge) }\end{array}$ & $\begin{array}{c}\text { Cats with } \\
\text { SARS-COV-2 } \\
\text { confirmed via } \\
\text { RT-PCR and } \\
\text { neutralizing } \\
\text { antibodies, but viral } \\
\text { isolation could not } \\
\text { identify the virus }\end{array}$ & $\begin{array}{c}\text { Newman et al. } \\
\text { (2020) }\end{array}$ \\
\hline Spain & $\begin{array}{l}\text { Cats of a person who } \\
\text { died due to COVID-19 } \\
\text { were examined, and } \\
\text { the viral sequences had } \\
\text { 99.99\% of homology }\end{array}$ & $\begin{array}{c}\text { One cat exhibited } \\
\text { general clinical } \\
\text { signs of respiratory } \\
\text { infection, however } \\
\text { it had comorbidities. } \\
\text { The second } \\
\text { cat remained } \\
\text { asymptomatic }\end{array}$ & $\begin{array}{c}\text { The symptomatic } \\
\text { cat tested positive } \\
\text { on RT-PCR in } \\
\text { nasal swabs; the } \\
\text { asymptomatic cat } \\
\text { tested negative. Both } \\
\text { cats had neutralizing } \\
\text { titers against protein } \\
\text { S and RBD but were } \\
\text { negative against } \\
\text { protein } \mathrm{N}\end{array}$ & $\begin{array}{l}\text { Segalés et al. } \\
\text { (2020) }\end{array}$ \\
\hline France & $\begin{array}{l}\text { Yes, owner had } \\
\text { COVID-19 before the cat } \\
\text { developed symptoms }\end{array}$ & $\begin{array}{l}\text { Developed general } \\
\text { clinical signs of } \\
\text { viral infection } \\
\text { approximately } 17 \\
\text { days after the owner }\end{array}$ & $\begin{array}{c}\text { Rectal and } \\
\text { nasopharyngeal } \\
\text { swabs positive in } \\
\text { RT-PCR, neutralizing } \\
\text { antibody titration }\end{array}$ & $\begin{array}{l}\text { Sailleau et al. } \\
\qquad(2020)\end{array}$ \\
\hline Italy & $\begin{array}{l}\text { Unable to establish } \\
\text { whether there was } \\
\text { contact with people } \\
\text { with COVID-19 or other } \\
\text { cats because the cat had } \\
\text { access to the street }\end{array}$ & $\begin{array}{l}\text { Dyspnea and } \\
\text { vesicular murmurs } \\
\text { at lung auscultation, } \\
\text { ground-glass pattern } \\
\text { in the lung, and swift } \\
\text { death (could not } \\
\text { assess whether the } \\
\text { cat died of COVID-19 } \\
\text { or another disease, } \\
\text { but the picture was } \\
\text { similar to that of } \\
\text { human development } \\
\text { of COVID-19) }\end{array}$ & $\begin{array}{c}\text { Detection of viral } \\
\text { RNA in pharyngeal } \\
\text { swab }\end{array}$ & $\begin{array}{l}\text { Musso et al. } \\
\quad(2020)\end{array}$ \\
\hline
\end{tabular}

Abbreviations: COVID-19, coronavirus disease; RBD, receptor-binding domain; RT-PCR, reverse transcription polymerase chain reaction 
To date, there is still no consensus on which techniques are the most suitable for detecting SARS-CoV-2 in cats. Upper airway swabs and rectal swabs for the detection of viral RNA by RT-qPCR have been used by several research groups, and the SARS-CoV-2 detection targets were N1 gene, Spike gene, and RBD segments (Bosco-Lauth et al., 202O; Garigliany et al., 202O; Halfmann et al., 2020; Musso et al., 2020; Sailleau et al., 2020; Segalés et al., 2020; Shi et al., 2020).

In the studies mentioned above, there was a tendency for cats to develop clinical signs at various times (3-17 days) after their infected owners showed symptoms (Garigliany et al., 2020; Newman et al., 2020; Sailleau et al., 2020; Segalés et al., 2020). In experimental models to assess the transmission in cats, the period of initial contact of the animals (inoculated and uninoculated) was 1-5 days (Gaudreault et al., 2020; Halfmann et al., 2020; Shi et al., 2020). These reports show that the prepatent period of SARS-CoV-2 infection in cats can vary from a few days to weeks and depends on the means of contamination: from humans with COVID-19, from the environment, or from other cats.

In naturally infected animals that could be tested from the beginning of the infection until the remission of clinical signs, the virus could no longer be detected 10 days after the first detection (Garigliany et al., 2020; Sailleau et al., 2020). This result corroborates the findings of Patterson et al. (2020) and reinforces the idea that the viremia period in cats is short.

In summary, it can be assumed that cats develop SARS-CoV-2 infection, with a prepatent period varying from 2 to 17 days. Cats can become infected through the respiratory route and perhaps orally and have a short period of viremia. However, the starting process of the infection has not been elucidated. Despite the detection of the virus in the upper airways, trachea, bronchioles, gastrointestinal tract, and feces, the virus was not detected in the blood (Bosco-Lauth et al., 2020; Gaudreault et al., 2020; Shi et al., 2020). Most infected cats remain asymptomatic or oligosymptomatic, and severe cases, as in humans, are associated with comorbidities (Musso et al., 2020; Segalés et al., 2020).

\section{Immunological aspects}

There is evidence that cats can develop neutralizing antibodies against RBD, nucleoprotein $\mathrm{N}$, and protein $\mathrm{S}$, with no cross-reaction of the serological tests used with other typical feline coronaviruses (Gaudreault et al., 2020; Shi et al., 2020; Zhang et al., 2020). It has been suggested that felines should also be used as models in the development of vaccines against SARS-CoV-2 because they have demonstrated resistance to reinfection and have high titers of neutralizing antibodies (Bosco-Lauth et al., 2020).

Furthermore, it is important to note that for the experimental infections, the inoculated animals had a high viral load and remained asymptomatic during the follow-up period. The few symptomatic clinical cases described in the literature, possibly due to natural infection, had a lower viral load. These findings, apparently paradoxical, need to be further studied.

\section{Final considerations}

Although some evidence on the role of domestic animals in the epidemiological routes of SARS-COV-2 demonstrates that they may not be an important route of transmission, further research and other aspects should be considered to establish the epidemiological part of domestic cats in the COVID-19 pandemics. Jo et al. (2020) hypothesized that the proportion of the current COVID-19 pandemic is due to animal reservoirs and disseminators.

In this scenario, there is scientific evidence for the natural transmission of the SARS-COV-2 virus from humans to cats, so much so that the virus sequenced in a cat and its owner, who developed symptoms before the animal, had 99.99\% homology (Segalés et al. 2020). There is also evidence of transmission between cats via the airborne route (Halfmann et al., 2020; Shi et al. 2020). These findings raise questions about whether there is really no transmission from cats to humans. Therefore, it is advisable for people with COVID-19 to adapt their quarantine measures and avoid contact with their cats.

Furthermore, due to the origins of coronaviruses in animals as the spillover ability of coronaviruses, other researchers have highlighted the need to study animals and the full zoonotic potential of this disease (Abdel-Moneim \& Abdelwhab, 2020; Deng et al., 202Ob; Leroy et al., 
2020; Paltrinieri et al., 2020; Sharun et al., 2020; Stout et al., 2020; Salajegheh Tazerji et al., 2020; Wang et al., 2020; Wu et al., 2020).

The role of domestic cats remains controversial as to whether animals would actually have a protective effect against SARS-CoV-2 in their owners has also been explored. Since the consistent exposure of animal owners to their pets, viral epitopes could modulate their immune response to be more effective against infection from this group of viruses (Jurgiel et al., 2020).

Regardless of what is concluded based on results from new studies, there is in fact a strong indication for the concepts of ONE HEALTH to be incorporated into the studies and practices of epidemiological surveillance of infectious diseases, with multidisciplinary teams that recognize the connection between human and animal health and environment.

The current pandemic and previous experiences with worldwide outbreaks (e.g., SARS-CoV, MERS-CoV, and H1N1) reinforce the need for actions based on ONE HEALTH approach worldwide, such as the 2007 recommendation (Cheng et al., 2007; Mobasheri, 2020) with a specific warning about a virus similar to SARS-CoV in bats from China with a great epidemic potential.

\section{Conclusions}

This review revealed the importance of continuing to study the relationship between SARS-CoV-2 infections in humans and cats, as a result of the biological nature of the infection, because the absolute number of cases of cross-infection, although relatively small, can reach a great value in terms of the human population in a global pandemic.

There is also a need for the concept of One Health to be incorporated into the study and practice of epidemiological surveillance of infectious diseases, with multidisciplinary teams that can look further, recognizing the connection between human and animal health.

\section{Ethics statement}

It is a review.

\section{Financial support}

This work was produced without funding.

\section{Conflict of interests}

All authors declare that's no conflict of interest..

\section{Authors' contributions}

AIPT - Conception, writing and review. LC - Conception, writing and review.

\section{Availability of complementary results}

Availability of complementary results: not applicable

The study was carried out at Faculty of Agronomy and Veterinary Medicine, University of Brasília, Brazil and Tropical Medicine Center, University of Brasília, Brasília, DF, Brazil.

\section{References}

Abdel-Moneim, A. S., \& Abdelwhab, E. M. (2020). Evidence for SARS-CoV-2 infection of animal hosts. Pathogens, 9(7), 529. http://dx.doi.org/10.3390/pathogens9070529. PMid:32629960.

Alexander, M. R., Schoeder, C. T., Brown, J. A., Smart, C. D., Moth, C., Wikswo, J. P., Capra, J. A., Meiler, J., Chen, W., \& Madhur, M. S. (2020). Predicting susceptibility to SARS-CoV-2 infection based on structural differences in ACE2 across species. The FASEB Journal, 34(12), 15946-15960. http://dx.doi.org/10.1096/fj.202001808R. PMid:33015868.

Barrs, V. R., Peiris, M., Tam, K. W. S., Law, P. Y. T., Brackman, C. J., To, E. M. W., Yu, V. Y. T., Chu, D. K. W., Perera, R. A. P. M., \& Sit, T. H. C. (2020). SARS-CoV-2 in quarantined domestic cats from COVID-19 households or close contacts, Hong Kong, China. Emerging Infectious Diseases, 26(12), 3071-3074. http://dx.doi.org/10.3201/ eid2612.202786. PMid:32938527. 
Belouzard, S., Millet, J. K., Licitra, B. N., \& Whittaker, G. R. (2012). Mechanisms of coronavirus cell entry mediated by the viral spike protein. Viruses, 4(6), 1011-1033. http://dx.doi.org/10.3390/v4061011. PMid:22816037.

Bosco-Lauth, A. M., Hartwig, A. E., Porter, S. M., Gordy, P. W., Nehring, M., Byas, A. D., VandeWoude, S., Ragan, I. K., Maison, R. M., \& Bowen, R. A. (2020). Experimental infection of domestic dogs and cats with SARS-CoV-2: Pathogenesis, transmission, and response to reexposure in cats. Proceedings of the National Academy of Sciences of the United States of America, 117(42), 26382-26388. http://dx.doi.org/10.1073/pnas.2013102117. PMid:32994343.

Brooke, G. N., \& Prischi, F. (2020). Structural and functional modelling of SARS-CoV-2 entry in animal models. Scientific Reports, 1O(1), 15917. http://dx.doi.org/10.1038/s41598-020-72528-z. PMid:32985513.

Cheng, V. C. C., Lau, S. K. P., Woo, P. C. Y., \& Yuen, K. Y. (2007). Severe acute respiratory syndrome coronavirus as an agent of emerging and reemerging infection. Clinical Microbiology Reviews, 20(4), 660-694. http://dx.doi. org/10.1128/CMR.00023-07. PMid:17934078.

Chiocchetti, R., Galiazzo, G., Fracassi, F., Giancola, F., \& Pietra, M. (2020). ACE2 Expression in the cat and the tiger gastrointestinal tracts. Frontiers in Veterinary Science, 7, 514. PMid:32903561.

Decaro, N., \& Lorusso, A. (2020). Novel human coronavirus (SARS-CoV-2): a lesson from animal coronaviruses. Veterinary Microbiology, 244, 108693. http://dx.doi.org/10.1016/j.vetmic.2020.108693. PMid:32402329.

Deng, J., Jin, Y., Liu, Y., Sun, J., Hao, L., Bai, J., Huang, T., Lin, D., Jin, Y., \& Tian, K. (202Oa). Serological survey of SARS-CoV-2 for experimental, domestic, companion and wild animals excludes intermediate hosts of 35 different species of animals. Transboundary and Emerging Diseases, 67(4), 1745-1749. http://dx.doi.org/10.1111/ tbed.13577. PMid:32303108.

Deng, J., Liu, Y., Sun, C., Bai, J., Sun, J., Hao, L., Li, X., \& Tian, K. (2020b). SARS-CoV-2 serological survey of cats in China before and after the Pandemic. Virologica Sinica, 35(6), 846-848. http://dx.doi.org/10.1007/s12250020-00284-5. PMid:32870451.

Dhama, K., Patel, S. K., Sharun, K., Pathak, M., Tiwari, R., Yatoo, M. I., Malik, Y. S., Sah, R., Rabaan, A. A., Panwar, P. K., Singh, K. P., Michalak, I., Chaicumpa, W., Martinez-Pulgarin, D. F., Bonilla-Aldana, D. K., \& Rodriguez-Morales, A J. (2020). SARS-CoV-2 jumping the species barrier: Zoonotic lessons from SARS, MERS and recent advances to combat this pandemic virus. Travel Medicine and Infectious Disease, 37, 101830. http://dx.doi.org/10.1016/j. tmaid.2020.101830. PMid:32755673.

European Centre for Disease Prevention and Control - ECDC. (2020). Detection of new SARS-CoV-2 variants related to mink. Stockholm: ECDC.

Garigliany, M., Van Laere, A.-S., Clercx, C., Giet, D., Escriou, N., Huon, C., van der Werf, S., Eloit, M., \& Desmecht, D. (2020). SARS-CoV-2 natural transmission from human to cat, Belgium, March 2020. Emerging Infectious Diseases, 26(12), 3069-3071. http://dx.doi.org/10.3201/eid2612.202223. PMid:32788033.

Gaudreault, N. N., Trujillo, J. D., Carossino, M., Meekins, D. A., Morozov, I., Madden, D. W., Indran, S. V., Bold, D., Balaraman, V., Kwon, T., Artiaga, B. L., Cool, K., García-Sastre, A., Ma, W., Wilson, W. C., Henningson, J., Balasuriya, U. B. R., \& Richt, J. A. (2020). SARS-CoV-2 infection, disease, and transmission in domestic cats. Emerging Microbes \& Infections, 9(1), 2322-2332. http://dx.doi.org/10.1080/22221751.2020.1833687. PMid:33028154.

Halfmann, P. J., Hatta, M., Chiba, S., Maemura, T., Fan, S., Takeda, M., Kinoshita, N., Hattori, S., Sakai-Tagawa, Y., Iwatsuki-Horimoto, K., Imai, M., \& Kawaoka, Y. (2020). Transmission of SARS-CoV-2 in domestic cats. The New England Journal of Medicine, 383(6), 592-594. http://dx.doi.org/10.1056/NEJMc2013400. PMid:32402157.

Jo, W. K., Oliveira-Filho, E. F., Rasche, A., Greenwood, A. D., Osterrieder, K., \& Drexler, J. F. (2020). Potential zoonotic sources of SARS-CoV-2 infections. Transboundary and Emerging Diseases, tbed.13872. http://dx.doi.org/10.1111/ tbed.13872. PMid:33034151.

Jurgiel, J., Filipiak, K. J., Szarpak, Ł., Jaguszewski, M., Smereka, J., \& Dzieciątkowski, T. (2020). Do pets protect their owners in the COVID-19 era? Medical Hypotheses, 142, 109831. http://dx.doi.org/10.1016/j.mehy.2020.109831. PMid:32428810.

Leroy, E. M., Ar Gouilh, M. A., \& Brugère-Picoux, J. (2020). The risk of SARS-CoV-2 transmission to pets and other wild and domestic animals strongly mandates a one-health strategy to control the COVID-19 pandemic. One Health, 10, 100133. http://dx.doi.org/10.1016/j.onehlt.2020.100133. PMid:32363229.

Luan, J., Lu, Y., Jin, X., \& Zhang, L. (2020). Spike protein recognition of mammalian ACE2 predicts the host range and an optimized ACE2 for SARS-CoV-2 infection. Biochemical and Biophysical Research Communications, 526(1), 165-169. http://dx.doi.org/10.1016/j.bbrc.2020.03.047. PMid:32201080.

Mathavarajah, S., \& Dellaire, G. (2020). Lions, tigers and kittens too: ACE2 and susceptibility to COVID-19. Evolution, Medicine, and Public Health, 2020(1), 109-113. http://dx.doi.org/10.1093/emph/eoaa021. PMid:32974030.

Mobasheri, A. (2020). COVID-19, companion animals, comparative medicine, and one health. Frontiers in Veterinary Science, 7, 522. http://dx.doi.org/10.3389/fvets.2020.00522. PMid:32923472.

Morais, H. A., Santos, A. P., Nascimento, N. C., Kmetiuk, L. B., Barbosa, D. S., Brandão, P. E., Guimarães, A. M. S., Pettan-Brewer, C., \& Biondo, A. W. (2020). Natural infection by SARS-CoV-2 in companion animals: A review of case reports and current evidence of their role in the epidemiology of COVID-19. Frontiers in Veterinary Science, 7, 591216. http://dx.doi.org/10.3389/fvets.2020.591216. PMid:33195627. 
Munnink, B. B. O., Sikkema, R. S., Nieuwenhuijse, D. F., Molenaar, R. J., Munger, E., Molenkamp, R., BouwmeesterVincken, N., van der Spek, A., Tolsma, P., Rietveld, A., Brouwer, M., Bouwmeester-Vincken, N., Harders, F., Hakze-van der Honing, R., Wegdam-Blans, M. C.A., Bouwstra, R. J., Geurts van Kessel, C., van der Eijk, A. A., Velkers, F. C., Smit, L. A.M., Stegeman, A., van der Poel, W. H.M., \& Koopmans, M. P. G. (2020). Jumping back and forth: anthropozoonotic and zoonotic transmission of SARS-CoV-2 on mink farms. bioRxiv. In press. https://doi.org/10.1101/2020.09.01.277152.

Musso, N., Costantino, A., La Spina, S., Finocchiaro, A., Andronico, F., Stracquadanio, S., Liotta, L., Visalli, R., \& Emmanuele, G. (2020). New SARS-CoV-2 infection detected in an Italian Pet cat by RT-qPCR from deep pharyngeal swab. Pathogens, 9(9), 746. PMid:32932800.

Newman, A., Smith, D., Ghai, R. R., Wallace, R. M., Torchetti, M. K., Loiacono, C., Murrell, L. S., Carpenter, A., Moroff, S., Rooney, J. A., \& Barton Behravesh, C. (2020). First reported cases of SARS-CoV-2 infection in companion animals: new York, March-April 2020.MMWR. Morbidity and Mortality Weekly Report, 69(23), 710-713. http:/l dx.doi.org/10.15585/mmwr.mm6923e3. PMid:32525853.

Paltrinieri, S., Giordano, A., Stranieri, A., \& Lauzi, S. (2020). Feline infectious peritonitis (FIP) and coronavirus disease 19 (COVID-19): are they similar? Transboundary and Emerging Diseases, 00, 1-14. http://dx.doi.org/10.1111/ tbed.13856. PMid:32985113.

Patterson, E. I., Elia, G., Grassi, A., Giordano, A., Desario, C., Medardo, M., Smith, S. L., Anderson, E. R., Prince, T., Patterson, G. T., Lorusso, E., Lucente, M. S., Lanave, G., Lauzi, S., Bonfanti, U., Stranieri, A., Martella, V., Basano, F. S., Barrs, V. R., Radford, A. D., Agrimi, U., Hughes, G. L., Paltrinieri, S., \& Decaro, N. (2020). Evidence of exposure to SARS-CoV-2 in cats and dogs from households in Italy. bioRxiv. In press. http://dx.doi. org/10.1101/2020.07.21.214346. PMid:32743588.

Ruiz-Arrondo, I., Portillo, A., Palomar, A. M., Santibáñez, S., Santibáñez, P., Cervera, C., \& Oteo, J. A. (2021). Detection of SARS-CoV-2 in pets living with COVID-19 owners diagnosed during the COVID-19 lockdown in Spain: a case of an asymptomatic cat with SARS-CoV-2 in Europe. Transboundary and Emerging Diseases, 68(2), 973-976. http://dx.doi.org/10.1111/tbed.13803. PMid:32810370.

Sailleau, C., Dumarest, M., Vanhomwegen, J., Delaplace, M., Caro, V., Kwasiborski, A., Hourdel, V., Chevaillier, P., Barbarino, A., Comtet, L., Pourquier, P., Klonjkowski, B., Manuguerra, J.-C., Zientara, S., \& Le Poder, S. (2020). First detection and genome sequencing of SARS-CoV-2 in an infected cat in France. Transboundary and Emerging Diseases, 67(6), 2314. PMid:32500944.

Salajegheh Tazerji, S., Magalhães Duarte, P., Rahimi, P., Shahabinejad, F., Dhakal, S., Singh Malik, Y., Shehata, A. A., Lama, J., Klein, J., Safdar, M., Rahman, M. T., Filipiak, K. J., Rodríguez-Morales, A. J., Sobur, M. A., Kabir, F., Vazir, B., Mboera, L., Caporale, M., Islam, M. S., Amuasi, J. H., Gharieb, R., Roncada, P., Musaad, S., Tilocca, B., Koohi, M. K., Taghipour, A., Sait, A., Subbaram, K., Jahandideh, A., Mortazavi, P., Abedini, M. A., Hokey, D. A., Hogan, U., Shaheen, M. N. F., Elaswad, A., Elhaig, M. M., \& Fawzy, M. (2020). Transmission of severe acute respiratory syndrome coronavirus 2 (SARS-CoV-2) to animals: an updated review. Journal of Translational Medicine, 18(1), 358. http://dx.doi.org/10.1186/s12967-020-02534-2. PMid:32957995.

Segalés, J., Puig, M., Rodon, J., Avila-Nieto, C., Carrillo, J., Cantero, G., Terrón, M. T., Cruz, S., Parera, M., NogueraJulián, M., Izquierdo-Useros, N., Guallar, V., Vidal, E., Valencia, A., Blanco, I., Blanco, J., Clotet, B., \& Vergara-Alert, J. (2020). Detection of SARS-CoV-2 in a cat owned by a COVID-19-affected patient in Spain. Proceedings of the National Academy of Sciences of the United States of America, 117(40), 24790-24793. http://dx.doi.org/10.1073/ pnas.2010817117. PMid:32948692.

Sharun, K., Sircar, S., Malik, Y. S., Singh, R. K., \& Dhama, K. (2020). How close is SARS-CoV-2 to canine and feline coronaviruses? The Journal of Small Animal Practice, 61(8), 523. http://dx.doi.org/10.1111/jsap.13207. PMid:32785948.

Shi, J., Wen, Z., Zhong, G., Yang, H., Wang, C., Huang, B., Liu, R., He, X., Shuai, L., Sun, Z., Zhao, Y., Liu, P., Liang, L., Cui, P., Wang, J., Zhang, X., Guan, Y., Tan, W., Wu, G., Chen, H., \& Bu, Z. (2020). Susceptibility of ferrets, cats, dogs, and other domesticated animals to SARS-coronavirus 2. Science, 368(6494), 1016-1020. http://dx.doi. org/10.1126/science.abb7015. PMid:32269068.

Stout, A. E., André, N. M., Jaimes, J. A., Millet, J. K., \& Whittaker, G. R. (2020). Coronaviruses in cats and other companion animals: Where does SARS-CoV-2/COVID-19 fit? Veterinary Microbiology, 247, 108777. http:/l dx.doi.org/10.1016/j.vetmic.2020.108777. PMid:32768223.

Sun, K., Gu, L., Ma, L., \& Duan, Y. (2020). Atlas of ACE2 gene expression in mammals reveals novel insights in transmisson of SARS-Cov-2. bioRxiv. In press. http://dx.doi.org/10.1101/2020.03.30.015644.

Temmam, S., Barbarino, A., Maso, D., Behillil, S., Enouf, V., Huon, C., Jaraud, A., Chevallier, L., Backovic, M., Pérot, P., Verwaerde, P., Tiret, L., van der Werf, S., \& Eloit, M. (2020). Absence of SARS-CoV-2 infection in cats and dogs in close contact with a cluster of COVID-19 patients in a veterinary campus. One Health, 10, 100164. http://dx.doi.org/10.1016/j.onehlt.2020.100164. PMid:32904469.

Ul-Rahman, A., Shabbir, M. A. B., Aziz, M. W., Yaqub, S., Mehmood, A., Raza, M. A., \& Shabbir, M. Z. (2020). A comparative phylogenomic analysis of SARS-CoV-2 strains reported from non-human mammalian species and environmental samples. Molecular Biology Reports, 47(11), 9207-9217. http://dx.doi.org/10.1007/s11033020-05879-5. PMid:33104993.

Wang, H., Wang, F., Wang, H., \& Zhao, Q. (2020). Potential infectious risk from the pets carrying SARS-CoV-2. Travel Medicine and Infectious Disease,35,101737. http://dx.doi.org/10.1016/j.tmaid.2020.101737. PMid:32380152. 
World Health Organization - WHO. (2020, November 5). Coronavirus disease (COVID-19) dashboard. https:// covid19.who.int/

Wu, L., Chen, Q., Liu, K., Wang, J., Han, P., Zhang, Y., Hu, Y., Meng, Y., Pan, X., Qiao, C., Tian, S., Du, P., Song, H., Shi, W., Qi, J., Wang, H.-W., Yan, J., Gao, G. F., \& Wang, Q. (2020). Broad host range of SARS-CoV-2 and the molecular basis for SARS-CoV-2 binding to cat ACE2. Cell Discovery, 6(1), 68. http://dx.doi.org/10.1038/s41421020-00210-9. PMid:33020722.

Zhang, Q., Zhang, H., Gao, J., Huang, K., Yang, Y., Hui, X., He, X., Li, C., Gong, W., Zhang, Y., Zhao, Y., Peng, C., Gao, X., Chen, H., Zou, Z., Shi, Z.-L., \& Jin, M. (2020). A serological survey of SARS-CoV-2 in cat in Wuhan. Emerging Microbes \& Infections, 9(1), 2013-2019. http://dx.doi.org/10.1080/22221751.2020.1817796. PMid:32867625. 